\title{
Contribution to the Knowledge of the Amphipoda 150. One new species of genus Niphargus (Gammaridea, Niphargidae) from France, Niphargus renei n.sp.
}

\author{
G. S. Karaman ${ }^{1}$
}

Keywords : Gammaridea, Niphargidae, new species, subterranean waters, Rhône, France,

One new species of the family Niphargidae (Amphipoda, Gammaridea), Niphargus renei $\mathrm{n}$. sp. is described from the subterranean waters of Rhône rjver near Lyon, France. This species is closely allied to the Niphargus orcinus - group of species.

Contribution à la connaissance des Amphipoda 150. Une nouvelle espèce du genre Niphargus (Gammaridea, Niphargidae) de France, Niphargus renei n. sp.

Mots-clès: Gammaridea, Niphargidae, nouvelle espèce, eaux souterraines, Rhône, France.

Une nouvelle espèce de la famille des Niphargidae (Amphipoda, Gammaridea), Niphargus renei, $n$. sp. souterraines du Rhône, près de Lyon, France. Cette espèce est très proche des espèces du Groupe Niphargus orcinus.

\section{Introduction}

The study of the subterranean members of Amphipoda in France has been provided by numerous scientists (Chevreux 1896, 1901, 1906 ; Schellenberg 1935, 1937, 1950, 1951 ; Coineau 1962, 1963, 1967. 1968 ; Balazuc 1954 ; Ginet 1962, 1982, 1985 ; Ginet \& Aellen, 1985 ; Ruffo 1954 ; Ruffo \& DelamareDeboutteville 1952; G. Karaman 1970, 1979, 1980 , 1982 ; Barbe 1961, 1963, 1965 ; Bou 1965, 1971 ; Platvoet 1984 , etc.), and numerous species were discovered and described. Among these genera, the genus Niphargus is presented with highest number of taxa (over 20) : some of these taxa are endemic for France, other one are with larger distribution in Europe.

Dr. René Ginet from the University of LyonVilleurbanne realized numerous investigations of the subterranean fauna in France during many years. He gave us kindly at disposition for study two samples of Niphargus from the subterranean waters

1. Biological Institute, P.O. Box 40. Titograd. Yugoslavia. of Rhône river near Lyon, described here as a new species, Niphargus renei, $\mathrm{n}$. sp., as well as detailed informations about previous citations of existence of $N$. renei in french scientific papers and photography of this species made by Jacques Mathieu.

\section{Niphargus renei n. sp.}

\section{Description}

Body length of ovigerous females up to $10 \mathrm{~mm}$. Body stout, metasomesegments 1-3 each with 2-4 short dorsoposterior setae. Urosome not laterally compressed, urosomite 1 on each side with 1 , rarely 2 spines ; urosomite 2 on each side with 2 spines (fig. III, 7), urosomite 3 smooth.

Head normal, lateral cephalic lobes short, subrounded, rostrum short (fig. I, 7).

Antenna 1 reaching or hardly exceeding half of the body-length ; peduncular segment 2 hardly shorter than ped. segment 1 (fig. I, 3), peduncular segment 3 slender, slightly exceeding half of second peduncular segment (fig. 1, 3); main flagellum consisting 
of up to 24 articles bearing one aesthetasc each (fig. I, 3); accessory flagellum 2- segmented, short, second segment exceeding half of first segment (fig. I, 4).

Antenna 2 slender, peduncular segments 4.5 poorly setose, peduncular segment 4 with several short dorsal spines also (fig. I, 5); flagellum slender, consisting of up to 9 articles; antennal gland cone short ( $f$ ig. I, 5).

Labrum broader than long, entire, convex, epistome prominent (fig. II, 7), subrounded distoanteriorly. Labium with well developed inner lobes (fig. II, 9).

Left mandible : incisor with 5 teeth, lacinia mobilis with 4 strong teeth, between incisor and molar appears a row of plumose setae. Right mandible : incisor with 4 teeth, lacinia mobilis feeble, bicuspidate, pluritoothed. Mandibular palp strong, with first segment smooth (fig. I, 6) ; second palp segment with nearly 8 strong spine-like setae ; third segment remarkably longer than second segment, subfalciform, bearing on outer face 1 group of A-setae, on inner face 4 groups of B-setae, at posterior margin up to $26 \mathrm{D}$-setae and up to 6 E-setae (fig. I, 6).

Maxilla 1 : inner plate with 1-2 setae, outer plate with 7 spines ( $5-6$ spines with one tooth, $1-2$ spines with 3-4 teeth each), palp 2- segmented not exceeding basis of spines of outer plate, bearing 3-4 distal long setae (fig. IV, 7-8).

Both plates of maxilla 2 with numerous distal setae only (fig. II, 8 ).

Maxilliped : inner plate very short, reaching only basis of first palp segment (fig. I, 1), bearing 2 distal spines and several setae; outer plate almost reaching half of second palp segment (inner margin) (fig. I, 1), bearing a row of distolateral spines; palp 4-segmented, large, nail shorter than the remaining part of article 4 ; palp article 4 with one seta at outer margin and one bunch of 2 setae at inner margin near basis of nail (fig. $I, 1$ ).

Coxae 1-4 distinctly longer than broad, with short marginal setae (fig. II, 1, 4; III, 1, 3), coxa 1 with subangular ventroanterior corner (fig. II, 1), coxa 4 poorly lobed ventroposteriorly (fig. III, 3), coxa 5 shorter than 4.

Gnathopods 1.2 large, gnathopod 2 slightly larger than 1. Gnathopod 1: segment 2 distally dilated, with concave anterior margin (fig. II, 1); segments
3-4 short, each with one group of setae at posterior margin ; segment 5 shorter than 6, narrow (fig. II, 1); segment 6 ovoid, with strongly inclinated convex palm defined on outer face by one strong corner spine accompagnied laterally by 3 , rarely only 2 short strong corner spines and 2 facial setae (fig. II, 2, 3), on inner face by one short subcorner spine (fig. II, 3) ; dactyl long and slender, with poorly marked inferior tooth near basis of nail, and bearing 3, rarely only 2 short setae at outer margin ; nail long and slender (fig. II, 2).

Gnathopod 2 : segment 2 narrower and not dilated distally (fig. II, 4); segments 3-4 short, with one group of setae at posterior margin ; segment 5 narrow and long, but shorter than segment 6 (fig. II, 4); segment 6 like that of gnathopod 1, but larger : palm strongly inclinated, defined on outer face by one long corner spine accompanied by one shorter spine sitting partially behind long spine (fig. II, 5, 6) and 2 facial setae ; on inner face by one shorter subcorner spine (fig. II, 6); dactyl like that of gnathopod 1.

Pereopods 3-4 slender and linear, segment 2 with concave anterior margin bearing short distolateral spines (fig. II, 1, 3) ; dactyl short, with one slender spine at inner margin and with one plumose seta at outer margin ; nail shorter than the remaining part of dactyl (fig. III, 1-4).

Pereopods 5-7 moderately long, peropod 5 slightly shorter than pereopods 6 and 7 ; segment 2 of pereopods 5.7 broad, dilated proximally, with short setae at posterior margin and with poorly developed but marked ventroposterior lobe (fig. IV, $1,3,5$ ) ; sometimes occurs one spine at posterior margin of segment 2 of pereopod 7 (fig. IV, 5); segments 3.6 with bunches of spines at both margins; dactyls short, with one spine at inner margin and with one plumose seta at outer margin; nail shorter than the remaining part of dactyl (fig. IV, 2, 4, 6).

Pleopods with 2 retinacula each. Anterior surface of peduncle of pleopods 1-2 with 2 short setae; peduncle of pleopod 3 at posterior surface with several setae including 2 distal setae.

Epimeral plates 1-3 angular, with straight or concave posterior margin (fig. III, 5), ventral margin of epimeral plates 2-3 with several spines each.

Urosomite 1 near basis of peduncle of uropod 1 with one strong short spine (fig. III, 7). Uropod 1 : peduncle with dorsal outer row of spines and dorsal 
inner row of setae (plus 1 distal spine); rami subequal long or inner ramus slightly longer than outer one (fig. III, 7), both rami with marginal and distal short spines.

Uropod 2 : peduncle with mid-dorsal spine (fig. III, 7), inner ramus distinctly longer than outer one, both rami with marginal and distal spines. Uropod 3 short, but distinctly exceeding tip of uropods 1.2 ; inner ramus scale-like, short ; outer ramus 2- seg. mented, short, second segment short (fig. III, 6).

Telson short, only poorly exceeding tip of pedun. cle of uropod 3, deeply incised, longer than broad (fig. I, 2) ; each lobe with 3 distal and 0-1 distolateral spines, dorsal spines absent. A pair of long plumose setae appears near the middle of each lobe.

Coxal gills occur on pereion-segments 2-6. Oostegites occur on pereion-segments 2.5 , setose (fig. III, 3).

Males like females in gnathopods, coxae, epimeral plates, maxilla 1 , uropods $I-3$, telson (fig. I, 8-10; IV, 8) (two available males up to $7.5 \mathrm{~mm}$ long each).

VARIABILITY : Inner plate of maxilla 1 with $1-2$ setae, often second seta is short or very short (fig. IV, 7, 8).

\section{Material examined}

France : By manual pumping upper level of phreatic water in the alluvial valley of the Rhone river, about $20 \mathrm{~km}$ to the east of Lyon, at 800 meters of the right bank of the Rhône river ; departement of Rhône, municipality of Balan. I.G.N. card $1 / 25,000$ of Montluel No. $1 / 2 ; X: 2095,45 ; 816,425$; altitude : $184 \mathrm{~m}$ (= "station 6 " in Gibert \& al. 1977), 18 May 1976 (4 spec., Rh 52) and 20 Oct. 1976 (3 spec., Rh 73).

HolotYPE : Ovigerous female of $10 \mathrm{~mm}$ length from $R h$ 52. Holotype and paratypes ( $R$ h 52$)$ are deposited in the Museum of Natural History in Verona, Italy. One paratype is deposited in Karaman's Collection in Titograd (Yugoslavia).

\section{Ecology}

Freshwater subter ranean species, it was found by several authors in the interstitial waters of the alluvial plain of Rhone river in the region of Lyon, up to 800 meters far from the river itself, accompanied by numerous other subterranean animals, including amphipods : Niphargus rhenorhodanensis Schell.,
N. kochianus Bate, Crangonyx sp., Niphargopsis caspary (Pratz) (Ginet 1982), Salentinella spp., etc. (Seyed-Reihani \& al. 1982; Dole 1983).

\section{Remarks and Affinities}

Niphargus renei has been cited from Rhône river in some works previous to this description, under the denomination of "Niphargus nova species $n$ or "Niphargus, espèce nouvelle". These mentions must be substitute for "Niphargus renei $»$ in the following publications: Gibert \& al. 1979, SeyedReihani 1980, Gibert \& al. 1981, Ginet 1982, Reygrobellet \& Dole 1982, Seyed-Reihani \& al. 1982, Dole 1983 a, Dole 1983 b.

Niphargus renei is allied to the species belonging to the Niphargus jovanovici-group by several characters (short uropod 3 in males, poorly developed sexual dimorphic characters, large gnathopods $\mathbf{1 . 2}$ with elevated number of corner spine on palm, by shape of mandibular palp, etc.). $N$. jovanovici-group of species differs from $N$. renei by presence of only one seta at outer margin of dactyl in gnathopods 1-2.

On the other hand, $N$. renei is similar also to the Niphargus orcinus- group of species (sensu S. Karaman 1950, G. Karaman 1972, 1984), by presence of several setae on outer margin of dactyl in gnathopods 1-2, short uropod 3 in males, large gnathopods $1 \cdot 2$, etc.

Niphargus gallicus Schell. 1935, known from Sète, Montpellier and Nice (France) (Chevreux 1901, Chevreux \& Fage 1925, Schell. 1935) and later from Romania (Dancau 1963) is provided with large oblique segment 6 of gnathopods 1-2, but this species differs from $N$. renei by elongated second segment of uropod 3 in males, by presence of only one seta at outer margin of dactyl in gnathopods 1-2, etc.

Graf and Straśkraba described (1967) a new subspecies $N$. jovanovici burgundus n. ssp. from Dijon (France) ; this taxon was later removed by G. Karaman (1980) to the specific rank. N. burgundus belongs to the $N$. jovanovici-group of species, having only one seta at outer margin of dactyl in gnathopods 1-2, telson with several very long plumose setae and dactyl of pereopods 3-7 with several spines along inner margin.

Dancau described (1964) Niphargus dobrogicus $n$. sp. from the subterranean waters of Romania near Black Sea coast; this species is very allied to 


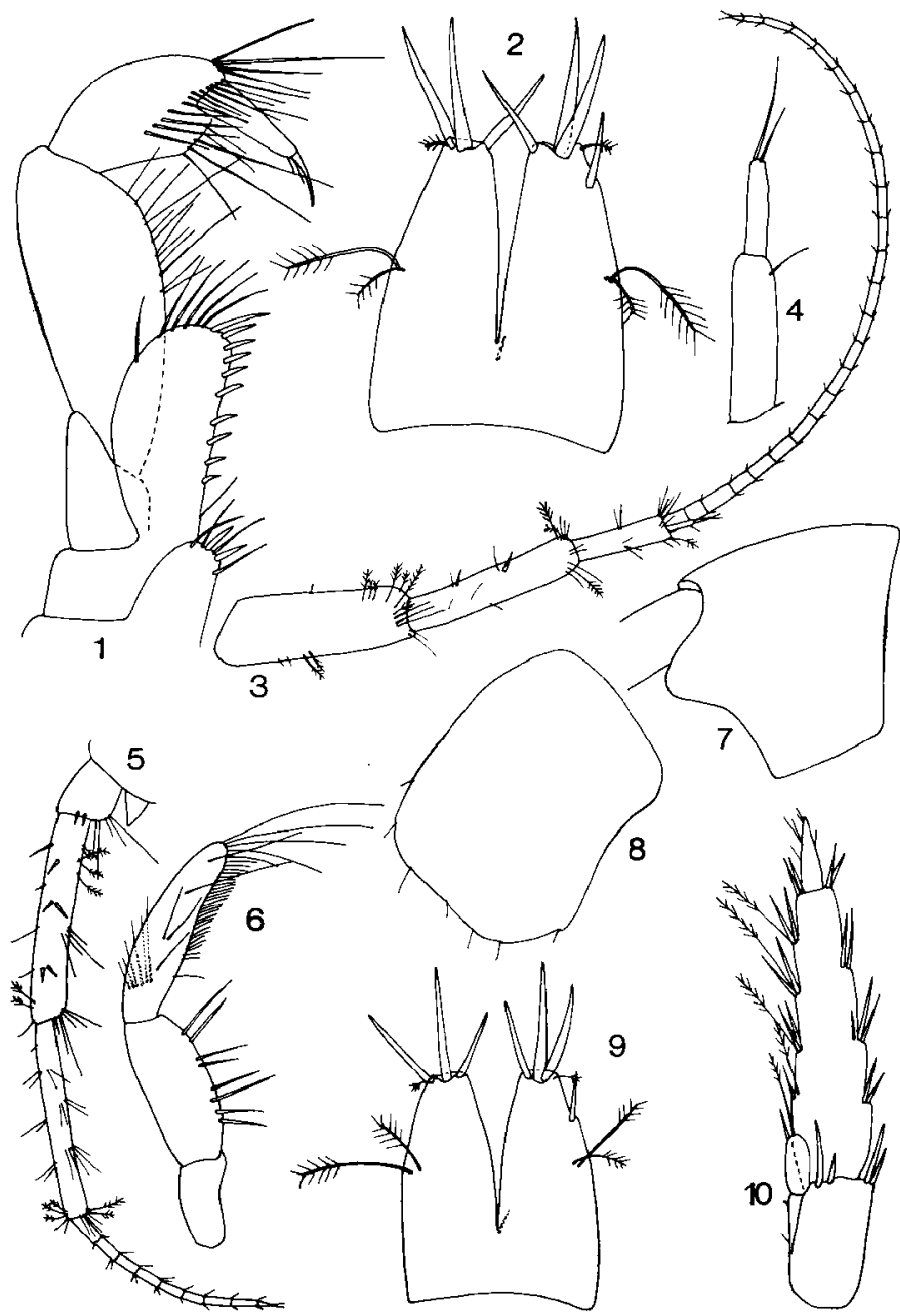

Figure 1. - Niphargus renei, n. sp., Rhòne river, Lyon (Rh 52), fermale $10 \mathrm{~mm}$.

1: maxilliped : 2 : telson ; $3:$ antenna $1 ; 4:$ accessory flagellum ; $5:$ antenna $2: 6:$ mandibular palp ; $7:$ head $; 8:$ coxa 4 , male $7,5 \mathrm{~mm} ; 9:$ telson, male $7,5 \mathrm{~mm} ; 10:$ uropod 3 , male $7,5 \mathrm{~mm}$. 


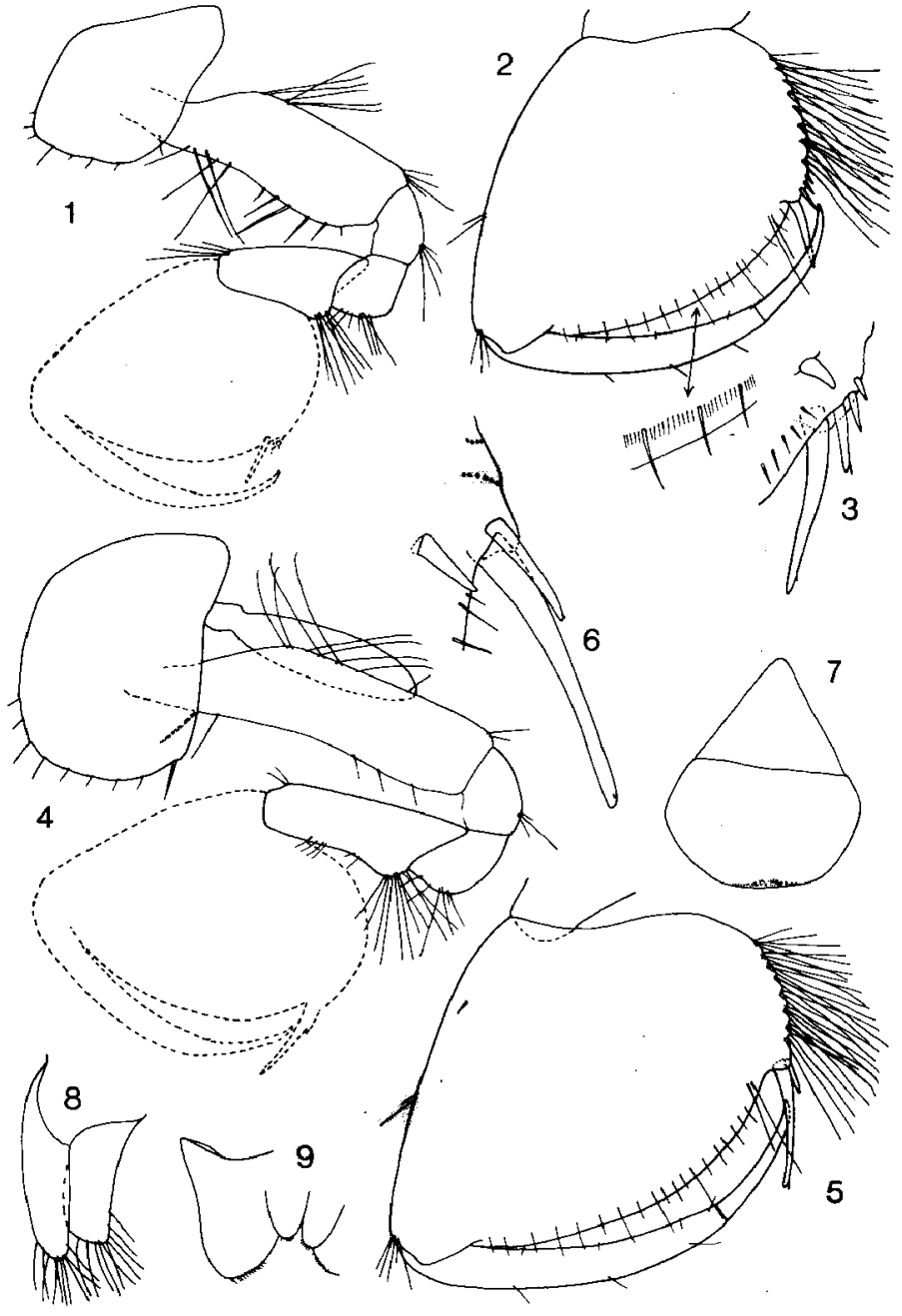

Figure II. - Niphargus renei, n. sp., Rhône river, Lyon (Rh 52), female $10 \mathrm{~mm}$. 1-3: gnathopod 1;46: gnathopod $2 ; 7$ : labrum; 8 : maxilla $2 ; 9$ : labium. 


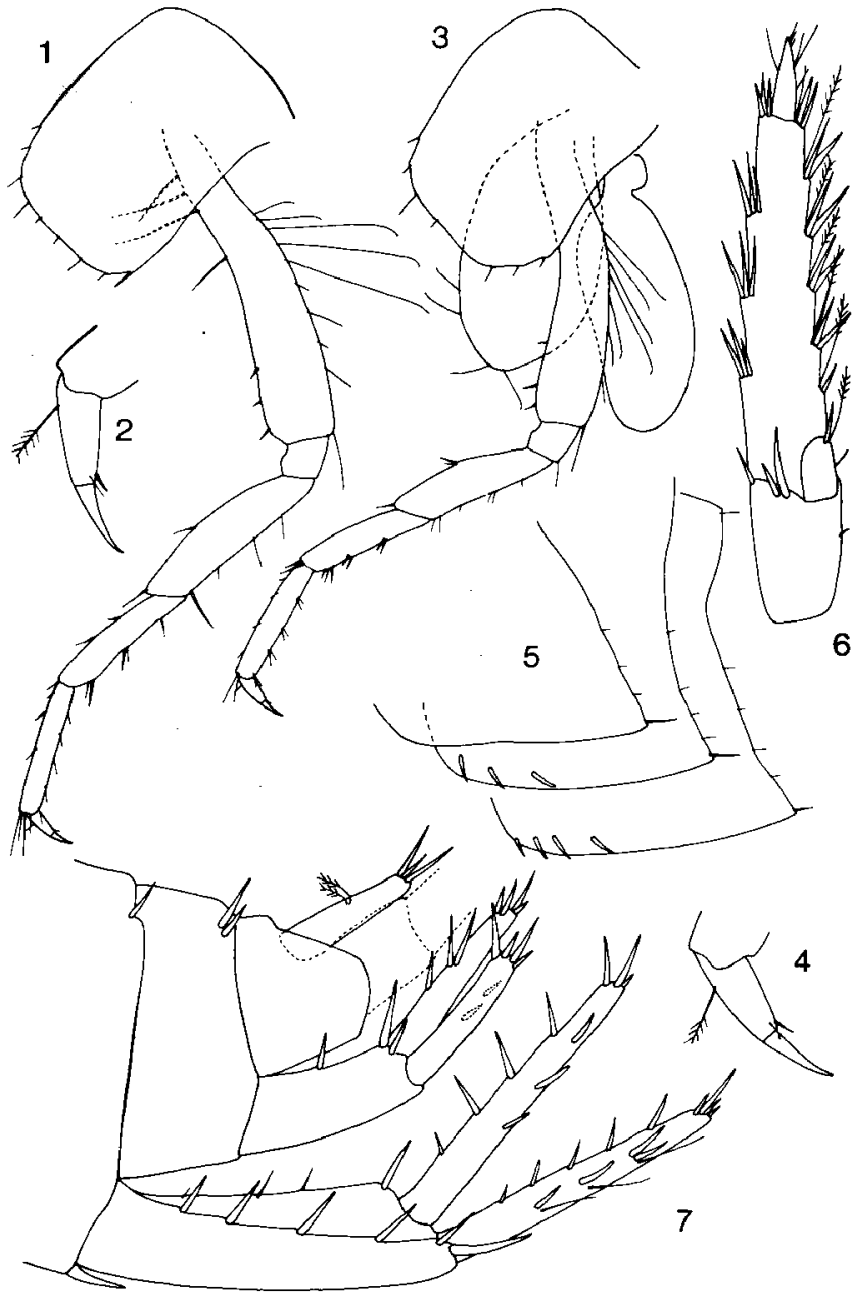

Figure III. - Niphargus renei, n. sp., Rhône river, Lyon (Rh 52), female $10 \mathrm{~mm}$.

1-2 : pereopod $3 ; 3-4:$ pereopod $4 ; 5:$ epimeral plates $1-3 ; 6:$ uropod $3 ; 7:$ urosome with uropods $1-2$. 


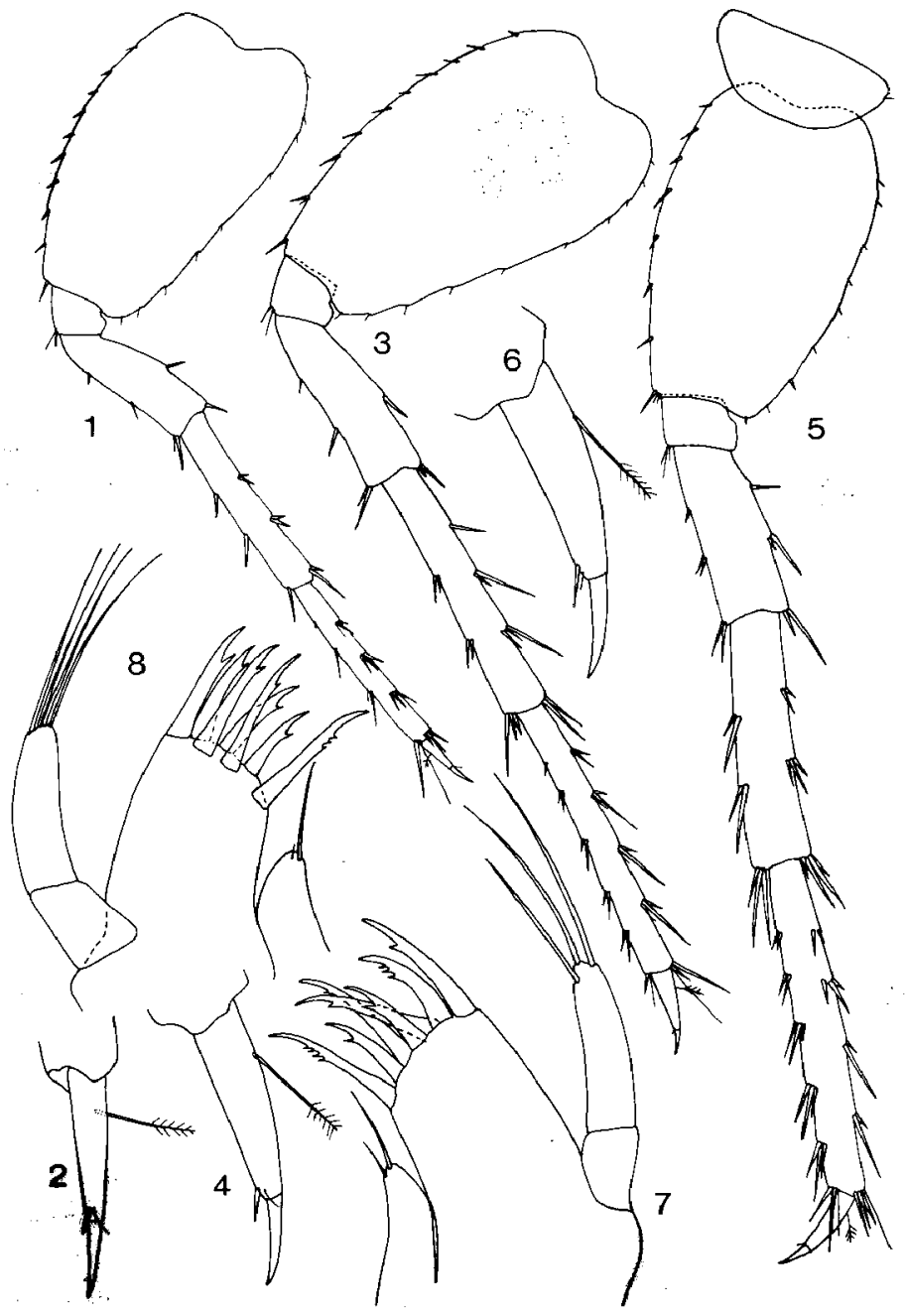

Figure IV. - Niphargus renei, n. sp., Rhône river, Lyon (Rh 52), female $10 \mathrm{~mm}$. 1.2 : pereopod $5 ; 3.4:$ pereopod $6 ; 5-6:$ pereopod $7 ; 8:$ maxilla 1 , male $7.5 \mathrm{~mm}$. 


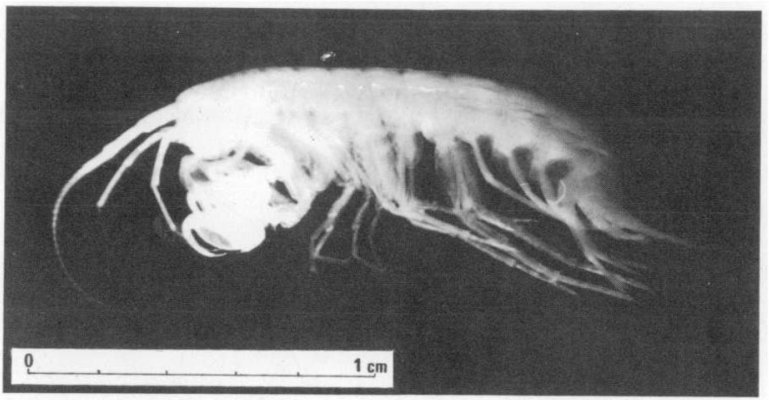

Figure V. - Niphargus renei, n. sp. Rhône river, Lyon : entire animal (clichè J. Mathieu).

$N$. renei, but differs from later by telson bearing long subdistal plumose setae and pleopods with 8-9 retinacula each.

Dershavin described (1945) Niphargus kurdus, $\mathrm{n}$. sp. from the subterranean waters of bassin of Akeri river (Transcaucasus, USSR), one species with large ovoid gnathopods $1-2$ bearing several setae at outer margin of dactyl, by short uropod 3, short plumose setae on telson, etc. $N$. renei differs from it by larger segment 2 of pereopods 5-7, by broader telson, etc.

ETYMology: The specific name is proposed in honour of Prof. Rene Ginet, from the University Claude-Bernard in Lyon-Villeurbanne (France) for his numerous contributions to the knowledge of the subterranean fauna of France.

\section{CONCLUSIONS}

The discovery of new species of subterranean amphipods from the interstitial waters of Rhone river in region of Lyon showed the high richness of the subterranean fauna of Amphipoda in France, indicating the probability of discovery of other new taxa of the same genus in France. Niphargus renei is very allied to Niphargus orcints- group of species and $N$. jovanovici- group of species, known mainly from southern part of Europe.

\section{LITERATURE CITED}

Balazuc (J.). 1954. - Les Amphipodes troglobies et phréatobies de la faune Gallo-Rhénane, Arch. Zool. Exp. et Generale, 91 (1): 153-193.

Barbe (L.). 1961. - Formes nouvelles ou mal connues de Niphargus, Ann. Spéléol., 16 (2): 229-234.

Barbe (L.). 1953. - Une seconde espece du genre Salentinella (Crustacé Amphipode) trouvée dans les Pyrénées, Ann. Spéléol. 18 (3) : 333-342.

Barbe (L.). 1965. - Une nouvelle espèce de Gammaride du genre Salentinella Ruffo en Aquitaine. Ann. Spéléol. 20 (1) : 81-93.

Bou (C.). 1965. - Niphargus gineti, nouvel Amphipode Gammaridae des eaux souterraines du sud-ouesi de la France. Ann. Spéleol., 20 (2) : $271-288$.

Bou (C.). 1971. - Parasalentinella rouchi n.g., n. sp., des eaux souterraines des Pyrénées Françaises (Amphipoda, Garnmaridae), Ann. Speleol., 26 (2) : 481-494.

Chevreux (E.). 1896. - Sur un Amphipode d'eau douce, Niphargus virei n. sp. provenant des grot tes du Jura, Bull. Mus. Paris, 4 : 136-137.

Chevreux (E.). 1901. - Amphipodes des eaux souterraines de France et d'Algérie, I-IV, Bull. Soc. Zool. France 26 : 168-222.

Chevreux (E.). 1906. - Niphargus ciliatus n. sp., in : Peyerimhoff P., Recherches sur la faune cavemicole des Basses-Alpes, Ann. Soc. Entomol. France 75 : 203-222.

Chevreux (E.) \& Fage (L.). 1925. - Amphipodes, in Faune de France 9 : 1.488 , Paris.

Coineau (N.). 1962. - Salentinella delamarei, nouvel Amphipode Gammaridae des eaux phréatiques du Tech (PyrénéesOrientales), Vie et Milien 13 (3) : 507.520.

Coineau (N.). 1963 a. - Etude sur les Amphipodes II. Salentinella petiti n. sp. Vie et Milieu 14 (1): 107-122.

Coineau (N.). 1963 b. - Présence du sous-ordre des Ingolfiellidae Reibisch (Crustacea Amphipoda) dans les eaux souterraines continentales de France, C.R. Acad. Sc. Paris $256: 4729-4731$.

Coineau (N.). 1966. - Recherches sur la faune des iles méditerranéennes III. Isopodes et Amphipodes interstitiels de Corse et de Sardaigne, Vie et Milieu 17 (1 B) : 389-405. 
Coineau (N.). 1968. - Contribution à l'étude de la faune intersti tielie Isopodes et Amphipodes, Mem. Mus. Nat. Hist. Nat. Paris, nouv. serrie, Ser. A, 55 (3) : 147-216.

Dancau (D.). 1963. - Niphargus gallicus Schell., amfipod subteran nou pentru fauna R.P.R., Com. Acad. RPR 13 (2): 123-129.

Dancau (D.). 1964. - Noi contributii la studiul amfipodelor subte rane, Niphargas dobrogicus n. sp. Lucrarile Inst. Speol. " $E$ Racovitza \& Acad. RPR, Bucuresti, 3: 397.403.

Dole (M.J.). 1983 a. - Le domaine aquatique souterrain de la plaine alluviale du Rhòne à l'est de Lyon : I : diversité hydrologique et biocénotique de trois stations représentatives de la dynamique fluviale, Vie ei Milieu 33 (3-4) : 219-229.

Dole (M.J.). 1983 b. - Le domaine aquatique souterrain de la plaine alluviale du Rhône à l'est de Lyon ; écologie des niveaux supérieurs de la nappe. - Thèse 3" cycle Univ. Lyon I No. 1342 $168 \mathrm{p}$.

Gibert (J.), Ginet (R.), Mathieu (J.), Reygrobellet (J.L.) \& Seyed Reihani (A.). 1979. - Ecosystème souterrain du fleuve Rhòne en amont de Lyon. Bull. Cent. El. Rech. Sci. Biarritz 12 (3) 556-558.

Gibert (J.), Ginet (R.), Mathieu (J.) \& Reygrobellet (J.L.). 1981. Structure et fonctionnement des ecosystemes du Haut-Rhône français : IX : analyse des peuplements de deux stations phréa tiques alimentant des bras morts. Int. J. Spéléol. 11 : 141-158.

Ginet (R.). 1962. - Synonymie de Niphargus bispinosus Barbé. 1961 (Amphipode Gammaride hypogé), Ann Spelél. 17 (1) : 196-198.

Ginet (R.). 1982. - Structure et fonctionnement des écosystemes du Haut-Rhône français; XXIV : les Amphipodes des eaux interstitielles en amont de Lyon, Polskie Arch. Hydrobiol. 29 (2) : 231-237,

Ginet (R.). 1985. - Redescription du type de l'Amphipode hypoge Niphargus thenorhodanensis Schellenberg. 1937 (sic), Crustaceana 48 (3): 225-243.

Ginet (R.) \& Aellen (V.) 1985. - Synonymie de Niphargus godeti Wrzesniowski, 1890 et de Niphargus virei Chevreux, 1986 Revue Suisse Zool. 92 (1): 107-114.

Graf (F.) \& Straskraba (M.). 1967. - Sur une nouvelle sous-espece de Niphargus jovanovici Kar. (Crust. Amphipoda. Gammaridae) de Dijon, France, Int. J. Spétéol. 3:55-64.

Karaman (G.). 1970. - XXIV Beitrag zur Kenntnis der Amphipoden. Eine neue Art des Genus Neogammarus Ruffo aus Frank reich, Neogammarus (Longigammarus) bruni, n. sbg. n. sp. Fragmenia Balcanica, Skopje 7 (14): 125-135.

Karaman (G.). 1972. - Le problème du genre Niphargus en You. goslavie, Actes Icr Coll, Int. genre Niphargts, Verona 1969 Mem. Mus. civ. St. Nat. Verona fuori serie 5 : $1-10$

Karaman (G.). 1979. - Contribution to the Knowledge of the Amphipoda 92. Bogidiella chappuisi Ruffo 1952 and its variability with remarks to some other species (fam. Gammaridae) Poljoprivreda i sumarstvo, Titograd 25 (1) : 17-30.

Karaman (G.). 1980. - Revision of Niphargus jovanovici-group (Fam. Gammaridae) (Contribution to the Knowledge of the Amphipoda 110), Polioprivreda i sumarstvo, Titograd 26 (2) 3-22.
Karaman (G.). 1982. - Contribution to the Knowledge of the Amphipoda 125. First discovery of genus Niphargopsis Chevr. 1922 in Yugoslavia with revision of the genus (fam. Gammaridae). Poljoprivreda i sumarstvo, Titograd 28 (2): 87-103.

Karaman (G.). 1984. - Revision of the Niphargus orcinus-Group, part. I. (Fam. Niphargidae), (Contribution to the knowledge of the Amphipoda (30), Crnogorska Akademija Nauka in Umjet., Glas. Od. Prir. Nouka Titograd 4 : 7-79.

Karaman (S.). 1950. - Podrod Omiphargus u Jugoslaviji, I. dio, Srpska Akad. Nauka, Pos. Izdanja, Beograd 163 (2) : 119-136.

Morand-Chevat (C.). 1972. - Bilan actuel du genre Niphorgus en France et en Espagne. Actes Ier Coll. Int. genre Niphargus, Verona 1969, Mem. Mus. civ. St. Nat. Verona fuori serie 5 25. 31

Platvoel (D). 1984. - Observations on the genus Salentinella (Crustacea, Amphipoda) with description of Salentinella formente rae n. sp., Bijdragen tot de Dierkunde. Amsterdam 54 (2): 178-184.

Reygrobellet (J.L.) \& Dole (M.J.3. 1982. - Structure et fonctionnement des écosystèmes du Haut-Rhône français : XVI : Ie milieu interstitiel de la * zone du Grand-Gravier *: premiers résultats hydrologiques et faunistiques, Polskie Arch. Hydrobiol. 29 (2) : 485-500

Ruffo (S.). 1954 a. - Anfipodi di acque interstiziali raccolti dal Dr. C. Delamare Deboutteville in Francia, Spagna e Algeria, Vie et miliew, 4 (4) : 669-681.

Ruffo (S.). 1954 b. - Bogidiella chappuisi Ruffo, nouvel amphipode phréatobie de la faune française, Arch. Zool. exp. gén. 91 : 145-152.

Ruffo (S.) \& Delamare-Debout teville (C.). 1952. - Deux nouveaux Amphipodes souterrairs de France, Salentinella angelieri n. sp. et Bogidiella chappuisi n. sp., C.R. Acad Sci. Paris 234 1636-1638

Schellenberg (A.). 1935. - Schlüssel der Arnphipodengattung Niphargus mit Fundortangaben und mehreren neuen Formen, Zool. Anzeiger $111(7-8)$ : 204-211.

Schellenberg (A.). 1937. - Niphargen (Amphipoda) des Franzôsischen Jura und Jugoslawiens, Zool. Anzeiger 120 (7-8) : 161-169.

Schellenberg (A.). 1950. - Subterrane Amphipoden korsikanischer Biotope, Arch. Hydrobiol. 44 (2) : 325-332.

Schellenberg (A.), 1951. - Un Niphargus nouveau du Sudest de la France, Bull. Mus. nat. Hist. nat. Paris 23 (2) : $187-189$.

Seyed-Reihani (A.). 1980. - Etude écologique du milieu aquatique interstitiel lié au fleuve Rhône en amont de Lyon, Thèse Doct. 3e cycle Univ. Lyon-I No. $961: 70$ p.

Seyed-Reihani (A.), Ginet (R.) \& Reygrobellet (J.L.). 1982. - Structure et fonctionnement des écosystèmes du Haut-Rhône français : XXX : le peuplement de trois stations interstitielles dans la plaine de Miribel-Jonage (Vallée du Rhöne en amont de Lyon), en relation avec leur alimentation hydrogéologique, Rev. franc. Sic. Eau 1: 163-174. 